\title{
Implementasi Program Rehabilitasi Narkoba Berbasis Masyarakat di Pusat Rehabilitasi Narkoba ar-Rahman Tegal Binangun Palembang
}

\section{Miswanto}

Program Pascasarjana

Universitas Islam Negeri Raden Fatah Palembang, Indonesia

Email: miswantomegang@yahoo.com

\section{Tarya}

MTs Riyadhus Sholihin Megang Sakti Musi Rawas, Indonesia

Email: tarya12@gmail.com

\begin{abstract}
Abstrak
Penelitian ini dilatarbelakangi oleh adanya pusat rehabilitasi narkoba di Sumatera Selatan yang dalam proses penerapannya berbasis masyarakat dengan menggunakan pendekatan Comunity yang berujung pada proses spiritual. Hasil penelitian menunjukkan bahwa Pertama, implementasi program rehabilitasi narkoba melalui tiga tahap yaitu, tahap biologis-medis, psikoterapi-psikologi, dan tahap moral-spiritual. Pada tahap biologismedis meliputi; detoksifikasi, mandi, dan memotong rambut serta kuku. Tahap psikoterapipsikologi meliputi; isolasi dan motivasi, tahap terakhir adalah tahap moral-spiritual meliputi; pendidikan dasar-dasar agama, sholat berjama'ah, zikir dan membaca al-Qur'an. Kedua, faktor pendukung dan penghambat, faktor pendukung yaitu; sarana prasarana yang mendukung, adanya perhatian dan kasih sayang pembimbing, dan adanya dukungan dari pemerintah. Faktor penghambat yaitu; keadaan pecandu yang parah dan tidak adanya dukungan dari orang tua. Ketiga, Output program rehabiilitasi narkoba yaitu; adanya perubahan perilaku dan mental, munculnya kesadaran untuk berhenti mengkonsumsi narkoba, munculnya ketaatan dalam beribadah, dan meningkatnya jumlah anak bina yang dinyatakan selesai menjalani proses rehabilitasi.
\end{abstract}

Kata Kunci: Implementasi program, rehabilitasi narkoba, berbasis masyarakat

Banyak fenomena yang terjadi pada saat ini, para pemuda mulai menghadapi krisis akhlak. Padahal pemuda merupakan tulang punggung negara, pemuda adalah harapan bangsa, dan pemuda merupakan penerus generasi tua, namun terkadang harapan tersebut seolah-olah punah manakala pemuda banyak 
Miswanto dan Tarya

Implementasi Program Rehabilitasi Narkoba Berbasis Masyarakat di Pusat Rehabilitasi Narkoba ar-Rahman Tegal Binangun Palembang

yang terjerumus kedalam penyalahgunaan narkotika, psikotropika, dan bahan aktif lainnya (narkoba).

Narkoba sudah menjadi hantu masyarakat. Narkoba telah menimbulkan akibat yang fatal terhadap masa depan bangsa. Dewasa ini, tingkat penyalahgunaan narkoba di Indonesia telah menjadi keprihatinan masyarakat. Dadang Hawari, seorang dokter yang juga psikolog, mengatakan bahwa bangsa ini perlu mengantisipasi masa yang akan datang. Indonesia akan menjadi sasaran pemasaran empuk bagi pengedar narkotika, alkohol dan zat aktif lainnya (Hawari, 1996, hal. 152).

Presiden Republik Indonesia Joko Widodo mengatakan bahwa peredaran dan penyalahgunaan narkoba menjadi masalah besar nomor satu yang harus segera di atasi. Semua kementrian dan lembaga harus bersinergi mengatasi masalah ini, mulai dari Badan Narkotika Nasional (BNN), Polisi Republik Indonesia (POLRI), Tentara Nasional Indonesia (TNI), Kementrian Hukum dan Hak Asasi Manusia, Kementrian Komunikasi dan Informatika (Kemkominfo), Kementrian Kesehatan (Kemenkes), Kementrian Sosial (Kemensos), semuanya betul-betul melakukan langkah-langkah yang terpadu. Dan yang paling terpenting adalah adanya pengawasan yang sangat ketat, terutama di lapas narkoba. Hal tersebut bisa dilakukan sebulan dua kali atau sebulan satu kali. Lapas harus dicek secara mendadak baik oleh BNN, Polri dan dibackup TNI. Karena peredaran disitu bisa lebih dari 50\%. Selain itu, masalah rehabilitasi bagi penyalahgunaan narkoba harus berjalan efektif, sehingga langkah pemberantasan penyalahgunaan narkoba bisa efektif (News, 2016).

Badan Narkotika Nasional (BNN) Provinsi Sumatera Selatan (Sumsel) mendata hingga Juli 2015 ini, lebih dari 16.000 pemuda di Provinsi Sumsel mengkonsumsi atau menyalahgunakan narkotika, zat adiktif, dan obat-obatan berbahaya lainnya. Sementara, jumlah pengguna narkotika di Sumsel mengalami peningkatan setiap tahun seiring dengan peran daerah yang tidak sebatas tempat transit peredaran narkoba. Pemerintah provinsi Sumsel mendata telah memiliki 1,5 persen pecandu narkoba dari total penduduk yang berjumlah 7.222.635 jiwa (data BNN tahun 2012) atau sekitar 83.000 hingga 100.000 orang (Indonesia, 2008, hal. 2). Perang melawan narkoba merupakan tanggung jawab bersama, bukan tanggung jawab orang perorangan atau tanggung jawab pemerintah saja. Namun semua harus saling bahu membahu dan seluruh usaha ke arah tersebut harus dioptimalkan. Salah satu buktinya adalah bahwa masalah narkoba itu telah mendapat perhatian khusus dari berbagai macam lembaga, baik negeri maupun swasta. Berbagai pihak telah 
berusaha sekuat tenaga untuk menanggulanginya sebagai usaha untuk menekan seminimal mungkin dampak yang timbul akibat pemakaian obat-obat terlarang di tengah masyrakat. Telah digelar berbagai seminar dan symposium dengan tujuan membendung arus penyebaran narkoba. Berbagai macam memorandum telah ditandatangani dalam upaya penanggulangannya. Semua itu merupakan bukti kesungguhan bangsa ini untuk memerangi dan melawan bahaya narkoba.

Sementara itu, menurut M. Iswandi Hari Kepala Badan Narkotika Propinsi (BNP) Sumsel menuturkan bahwa solusi dalam pencegahan penyalahgunaan narkoba dapat dilakukan dengan tiga hal, yaitu: Pertama, Memperkuat posisi keluarga agar terjalin harmonis, Kedua, Isi waktu dengan kegiatan positif, Ketiga, Agama sebagai benteng yang paling kokoh dalam pencegahan penyalahgunaan narkoba (Sumsel, 2016).

Namun perlu diingat bahwa keluarga atau orang tua mempunyai andil yang sangat besar dalam pencegahan penyalahgunaan narkoba oleh remaja. Sudah saatnya bagi para orang tua mempersiapkan anak-anaknya menjadi generasi yang tangguh, berkepribadian dan bebas dari penyalahgunaan narkoba. Orang tua sebaiknya menyadari bahwa sudah menjadi tanggung jawabnya untuk mendidik para generasi selanjutnya agar memiliki kualitas sebagai manusia Indonesia yang handal dan berkepribadian. Pendidikan harus dimulai sejak awal yaitu sejak dalam kandungan ibu yang kemudian selanjutnya berlanjut pada pendidikan formal yakni sekolah.

Salah satu upaya dalam proses penyadaran terhadap pecandu narkoba, sumatera selatan melalui BNN Provinsi Sumsel telah bekerja sama dengan yayasan pusat rehabilitasi Ar-Rahman yang ada di daerah Tegal Binangun Jakabaring Palembang. Selain sebagai tempat untuk menimba ilmu oleh para santri, yayasan Ar-Rahman juga menyediakan program rehabilitasi untuk para pengguna narkoba. Dalam kaitannya dengan program rehabilitasi pecandu narkoba ini, ada hal yang menarik mengenai Pusat rehabilitasi narkoba di pusat Rehabilitasi Ar-Rahman. Pertama, Rehabilitasi narkoba Ar-Rahman merupakan satu-satunya lembaga pendidikan Islam dibawah manajemen yayasan pesantren di Sumatera Selatan yang khusus menangani masalah rehabilitasi pecandu narkoba. Kedua, Berdasarkan surve awal oleh peneliti, Yayasan Pusat Rehabilitasi Narkoba Ar-Rahman dalam penyembuhan narkoba menggunakan terapi comunity yang berujung pada proses spiritual. Hal tersebut berbeda dengan Pusat rehabilitasi oleh lembaga-lembaga sosial lain yang memfokuskan pada pendekatan medis, psikiatris, sosial dan 
Miswanto dan Tarya

Implementasi Program Rehabilitasi Narkoba Berbasis Masyarakat di Pusat Rehabilitasi Narkoba ar-Rahman Tegal Binangun Palembang

reaksional. Ketiga, Lokasi rehabilitasi narkoba yang sejuk dan jauh dari keramaian, sehingga sangat tepat untuk proses terapi terhadap pecandu narkoba.

\section{Metode Penelitian}

Berdasarkan tujuan penelitian yang menganalisis dan menjelaskan tentang pelaksanaan program rehabilitasi pecandu narkoba di pondok pesantren ArRahman, maka penelitian ini merupakan penelitian naturalistik atau kualitatif dengan pendekatan deskriptif.

Penelitian ini dilakukan di pusat Rahabilitasi Narkoba Ar-Rahman Kelurahan Plaju Darat, Kecamatan Plaju, Kota Palembang, Provinsi Sumatera Selatan dari Senin 11 Maret 2016 sampai hari Jum'at 11 Oktober 2016 mulai dari proses observasi tempat, pengumpulan dokumen, observasi penelitian, dan wawancara.

Untuk mengumpulkan data dalam penelitian ini menggunakan beberapa metode. Data dalam penelitian ini dikumpulkan melalui: metode observasi, wawancara, dan studi dokumentasi. Sedangkan analisis data menggunakan tiga prosedur yaitu Reduksi data, display data, dan verifikasi data.

\section{Hasil Penelitian dan Pembahasan}

1. Implementasi Program Rehabilitasi Narkoba Berbasis Masyarakat di Pusat Rehabilitasi Narkoba Ar-Rahman Palembang

Hakikat dari pembangunan serta pendirian Rehabilitasi Narkoba Ar-Rahman adalah menampung dan memberi pelayanan yang maksimal bagi korban narkoba dan pelayanan konseling bagi ODHA (Orang Dengan HIV/IDS) di seluruh lapisan masyarakat, yang pada saat itu belum ada lembaga rehabilitasi bagi pecandu narkoba yang berbasis religi dan berbasis masyarakat di Palembang. Dalam penerapan program rehabilitasi narkoba, yayasan Ar-rahman memiliki 3 program unggulan, yaitu program reguler, program khusus, dan program untuk anak sekolah (Sahrizal, 2016).

Program reguler merupakan program yang diperuntukkan bagi para pecandu secara umum. Dalam program reguler ini biasanya diisi oleh orang-orang dewasa yang memiliki masalah tentang penggunaan zat. Program khusus merupakan program yang diperuntukkan bagi pecandu narkoba yang sedang bekerja. Sedangkan program untuk anak sekolah diperuntukkan bagi para remaja yang sedang dalam masa sekolah, mulai dari SMP, SMA dan Perguruan tinggi. 
Proses terapi yang harus diikuti oleh masing-masing kelompok tersebut pada dasarnya sama. Hanya ada beberapa hal yang membedakannya, misalnya untuk orang yang sedang bekerja akan mendapatkan pelayanan khusus dalam pelayanannya konseling, karena orang yang sudah bekerja biasanya akan menjumpai masalah-masalah pribadi dalam pekerjaannya sehingga membuat orang tersebut depresi dan akhirnya terjerumus dalam penyalhgunaan narkoba. Sedangkan untuk anak di usia sekolah akan mengikuti proses belajar-mengajar seperti biasa di sekolah. Untuk permasalahan medis, penanganannya tergantung dengan kondisi tingkat keparahan pecandu narkoba.

Dalam aktivitas kegiatan proses rehabilitasi di Ar-Rahman tidak serta merta dilakukan hanya di lingkungan rehabilitasi semata, tetapi para anak bina/pecandu juga diikut sertakan dalam kegiatan sosial seperti gotong royong bersama-sama dengan warga sekitar. Selain itu juga, para pecandu bisa ikut berbaur bersama dengan santri-santri dan masyarakat yang ada di pondok pesantren Ar-Rahman.

Proses kegiatan rehabilitasi narkoba Ar-Rahman dilakukan mulai dari awal penerimaan anak bina sampai proses rehabilitasi dinyatakan selesai apabila pecandu memang sudah benar benar berhenti dan bertaubat untuk menggunakan zat haram tersebut. Hal ini dapat dilihat selama proses penerapan program sekaligus pengawasan selama berada di dalam pusat Rehabilitasi narkoba Ar-Rahman.

a. Penerimaan Anak bina Pusat Rehabilitasi Narkoba Ar-Rahman

Setiap pecandu narkoba yang akan masuk di Pusat Rehabilitasi Narkoba Ar-Rahman harus mengisi surat pernyataan dan perjanjian terlebih dahulu guna untuk menghindari hal-hal tidak diinginkan dimasa yang akan datang selama proses rehabilitasi narkoba di Pusat Rehabilitasi Narkoba ArRahman. Adapun isi dari surat pernyataan/perjanjian tersebut adalah: Klien wajib mematuhi dan mengikuti peraturan yang ada di Pusat Rehabilitasi Narkoba Ar-Rahman. Selanjutnya wali menyerahkan sepenuhnya keluarga untuk di rehabilitasi di Ar-Rahman. Apabila nantinya terjadi hal-hal yang tidak diinginkan selama proses rehabilitasi, maka wali tidak bisa menuntut ataupun meminta ganti rugi kepada pihak rehabilitasi. Setelah mengisi surat perjanjian dan pernyataan tersebut maka akan diadakan interview guna untuk mengetahui jenis zat yang di konsumsi dan tingkat keparahan pecandu narkoba. Setelah selesai, proses selanjutnya adalah wali melunasi administrasi yang telah ditetapkan.

Ada tiga macam penerimaan anak bina, yaitu masuk secara terpaksa, dipaksa dan suka rela. Adapun secara terpaksa itu biasanya dilatar 
belakangi oleh beberapa hal misalnya harta benda di rumah sudah habis sedangkan anak bina masih menjadi pecandu narkoba atau bisa juga karena pecandu menjadi DPO (Daftar Pencarian Orang) pada lembaga hukum tertentu, sehingga dia terpaksa untuk masuk di rehabilitasi narkoba Ar-rahman. Kalau secara dipaksa biasanya hal tersebut di dorong oleh orang tua anak bina karena mengetahui keluarga atau anaknya kedapatan menjadi pengkonsumsi narkoba sehingga orang tua memaksa anaknya untuk masuk di rehabilitasi narkoba Ar-rahman, atau bisa juga anak bina tertangkap kemudian diadili dan diputuskan oleh pengadilan untuk menjalankan rehabilitasi. Sedangkan yang sukarela biasanya mereka menyadari telah menjadi pecandu narkoba dan ingin berusaha untuk pulih dan sadar, sehingga alternatifnya adalah masuk di rehabilitasi narkoba Arrahman. Dari ketiga macam anak bina tersebut yang berpotensi untuk cepat pulih dan sadar adalah anak bina yang masuk secara sukarela. Karena dengan masuknya secara sekuarela, akan membuat mereka lebih cepat untuk mengikuti dan beradaptasi dalam menyesuaikan program yang ada.

Peningkatan jumlah klien dari tahun ke tahun merupakan salah satu indikasi bahwa pecandu narkoba di Indonesia, khususnya Sumatera Selatan dari tahun ketahun mengalami peningkatan. Selain itu, peningkatan klien di Pusat Rehabilitasi Narkoba Ar-Rahman juga bisa karena pelaksanaan program yang diterapkan di Pusat Rehabilitasi Narkoba Ar-Rahman Palembang telah berhasil dan memuaskan.

Wawancara dengan Novizar selaku sekretaris dan konselor menjelaskan bahwa, dari tahun ke tahun jumlah klien yang ada di Pusat Rehabilitasi Narkoba Ar-Rahman selalu bertambah. Dari catatan yang saya miliki bahwa pada tahun 2012 terdapat 34 klien, pada tahun 2013 ada 54 klien, pada tahun 2014 terdapat 72 klien, tahun 2015 ada 100 klien, dan pada tahun 2016 terdapat 75 klien. Memang pada tahun ini jumlahnya masih dibawah tahun 2015, tetapi tidak menutup kemungkinan dalam waktu 2 bulan ini pasti akan bertambah (Novizar, 2016).

Adapun jumlah klien yang ada di Pusat Rehabilitasi Narkoba Ar-Rahman Palembang dari tahun 2012 sampai tahun 2016 dapat dilihat pada grafik berikut: 


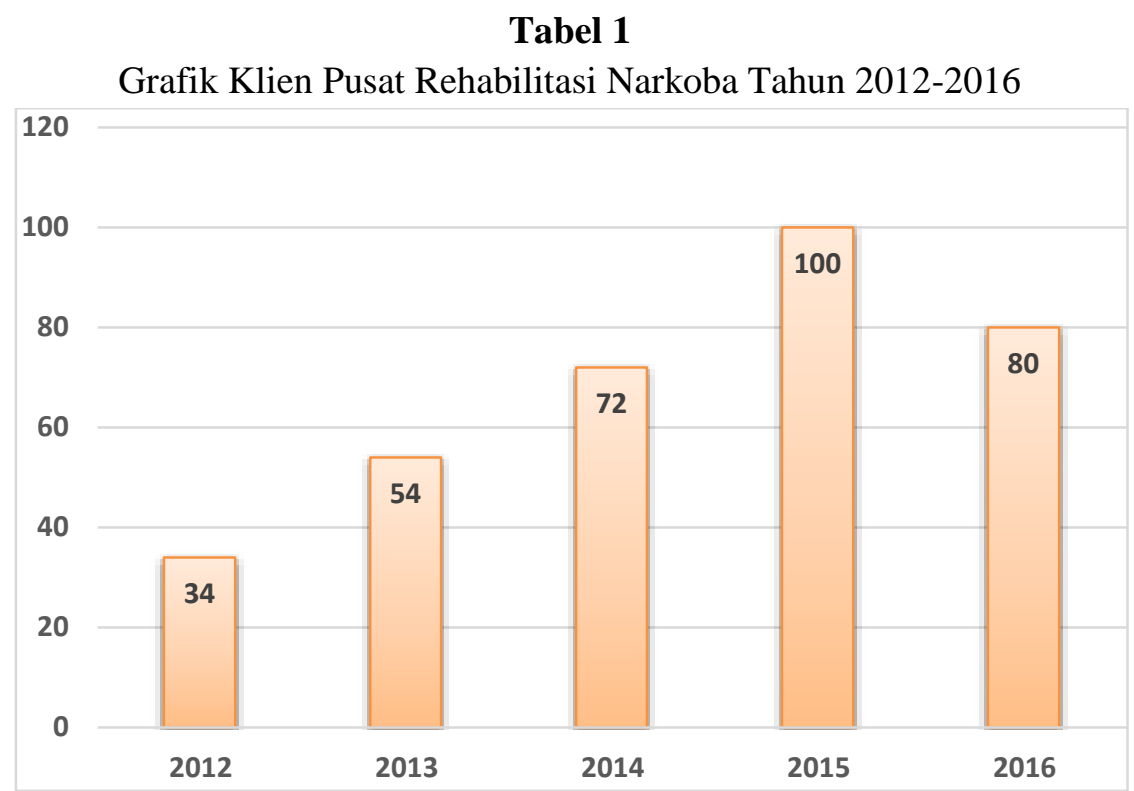

Sumber: Dokumentasi Pusat Rehabilitasi Narkoba Ar-Rahman Palembang tahun 2012-2016

Dari grafik di atas menggambarkan bahwa jumlah klien yang masuk di Pusat Rehabilitasi Narkoba Ar-Rahman mengalami peningkatan pada setiap tahunnya. Pada tahun 2012 terdapat 34 anak bina, pada tahun 2013 ada 54 anak bina, pada tahun 2014 terdapat 72 anak bina, tahun 2015 ada 100 anak bina, dan pada tahun 2016 terdapat 80 anak bina. Data tersebut diperoleh dari arsip dokumentasi klien pecandu narkoba yang ada di Pusat Rehabilitasi Narkoba Ar-Rahman palembang terhitung dari bulan Januari tahun 2012 hingga bulan Oktober 2016. Pada tahun 2016 jumlah klien ada 80 orang terhitung dari bulan Januari hingga Oktober, yang mana jumlah tersebut akan bertambah sampai bulan Desember 2016.

b. Schedule Harian Pusat Rehabilitasi Narkoba Ar-Rahman

Berdasarkan data tentang program rehabilitasi yang harus dilakukan oleh anak bina yang telah dijadwalkan oleh pengurus, terlihat bahwa anak bina harus mengikuti program dari pukul 04.30 wib sampai pukul 22.00 wib. Apabila diakumulasikan berarti dalam waktu 18,5 jam dalam sehari anak bina melaksanakan program setiap harinya. Sedangkan untuk istirahat hanya 5,5 jam dalam sehari. Hal tersebut dapat dilihat pada tabel dibawah ini. 
c. Proses Rehabilitasi

Proses rehabilitasi narkoba Ar-rahman Palembang dilakukan secara integratif mulai dari proses biologis medis, proses psikologis dan proses spiritual. Dalam penerapannya tidak serta merta harus dilakukan secara berurutan, tetapi dilakukan sesuai dengan kebutuhan dari anak bina/pecandu. Sehingga ke tiga proses tersebut dapat dikombinasikan secara bergantian. Adapun proses integratif tersebut adalah sebagai berikut:

1) Proses Biologis Medis

Proses biologis medis ini dilaksanakan dalam rangka mempersiapkan pecandu untuk menjalani proses rehabilitasi selanjutnya. Pada proses biologis ini difokuskan pada kondisi fisik para pecandu agar dapat pulih seperti keadaan sebelumnya. Pada terapi biologis medis ada beberapa proses yang dilaksanakan antara lain detoksifikasi, mandi, pemotongan rambut dan kuku.

Pertama, Detoksifikasi merupakan salah satu proses awal medis yang harus dijalani oleh pecandu narkoba ketika akan mengikuti program rehabilitasi yang lain. Proses detoksifikasi dilakukan dengan tujuan untuk membuang racun-racun yang berada pada tubuh pecandu narkoba, sehingga pecandu narkoba bisa mengikuti proses-proses selanjutnya. Adapun tujuan dari detoksifikasi sendiri adalah untuk mendorong sistem kekebalan agar bekerja efektif, memulihkan energi dan membersihkan darah. Liver sebagai organ pusat detoks mula-mula akan merubah sifat racun dari toksin menjadi netral. Setelah itu, toksin yang sudah dinetralkan diubah menjadi senyawa larut air kemudian dibuang melalui urin, keringat atau buang air besar (Nuraini, 2014, hal. 72).

Kedua, Mandi. Mandi yang dilakukan pertama kali adalah mandi taubat. Mandi taubat dilaksanakan dengan niat bertaubat dan membersihkan jiwa serta raga dari berbagai dosa yang telah terlanjur diperbuat sehingga kembali bersih dan menjadi penebus dosa-dosa dalam diri manusia. Caranya dengan mengalirkan air mulai dari ujung rambut sampai ujung kaki. Tiap air yang mengalir membasahi tubuh dimaksudkan untuk memberikan penyegaran terhadap fisik dan psikologis, disamping sebagai upaya untuk mengurangi rasa ketergantungan dan keinginan anak bina terhadap pemakaian 
narkoba.Dengan adanya rutinitas mandi akan membuat badan menjadi segar dan bersemangat. Selain dapat membuat tubuh segar, mandi juga akan membersihkan badan dari kotoran-kotoran yang menempel pada tubuh.

Ketiga, Pemotongan rambut dan kuku.Rambut dan kuku merupakan dua simbol penampilan yang mencolok pada pecandu narkoba. Rambut dan kuku pecandu narkoba seringkali tidak di perhatikan, sehingga terlihat acak-acakan dan kotor. Dengan tidak terurusnya rambut dan kuku tersebut maka dapat mempengaruhi sistim saraf yang digunakan untuk berfikir kearah positif. Pemotongan rambut dan kuku dilakukan pertama kali adalah ketika pecandu narkoba sudah melaksanakan mandi dengan tujuan untuk menjaga penampilan dan kesehatan pecandu narkoba. Selain dilakukan pada saat pertama kali masuk di pusat Rehabilitasi Narkoba Ar-Rahman, potong rambut dan kuku juga dilakukan sesuai dengan kebutuhan.

2) Proses Psikologis

Proses psikologis dilakukan untuk membantu dalam menyelesaikan permasalahan-permasalahan psikologis yang dialami oleh pecandu narkoba. Permasalahan-permasalahan psikologis muncul sebagai akibat dari penggunaan narkoba secara terus-menerus yang berakibat pada kerusakan dan gangguan fisik pecandu narkoba. Penggunaan zat narkoba yang dilakukan secara terus menerus ini apabila dihentikan akan berakibat pada munculnya reaksi-reaksi fisik dan psikologis pecandu narkoba. Dengan adanya putus zat, pecandu narkoba akan merasakan kesakitan yang luar biasa dan kejiwaannya akan tergoncang. Dalam keadaan seperti inilah, bimbingan psikologis sangat diperlukan untuk menenangkan dan mengembalikan kondisi kejiwaan pecandu narkoba. Pada proses psikologis, ada beberapa tahap yang akan dilakukan oleh pendamping atau terapis, diantaranya adalah isolasi dan motivasi.

Pertama, Isolasi. Isolasi merupakan mengasingkan pecandu narkoba ke dalam sebuah ruangan atau kamar yang bertujuan untuk pemutusan zat narkoba yang sebelumnya sering di konsumsi.Dengan kondisi di isolasi, psikologi kejiwaan pecandu narkoba akan mengalami perubahan, mulai dari sering ngomong sendiri atau ilusi, berteriak-teriak dengan maksud untuk memberontak, dan murung. 
Miswanto dan Tarya

Implementasi Program Rehabilitasi Narkoba Berbasis Masyarakat di Pusat Rehabilitasi Narkoba ar-Rahman Tegal Binangun Palembang

Kondisi pecandu narkoba pada saat di isolasi emosinya tidak setabil sehingga akan perhatian oleh pendamping. Setelah kondisi pecandu narkoba sudah tenang dan setabil, maka pecandu narkoba diajak untuk mandi dan berwudhu sembari berzikir mengucap lafaz "Allah" sebanyak-banyaknya oleh pendamping.

Kedua, Motivasi. Motivasi merupakan gejala psikologis dalam bentuk dorongan yang timbul pada diri seseorang secara sadar untuk melakukan suatu tindakan dengan tujuan tertentu (Charisa, 2016). Pada saat putus zat atau sakau, psikologi pecandu narkoba akan terguncang, sehingga pecandu narkoba membutuhkan pendampingan dan motivasi. Motivasi diberikan oleh pendamping setelah pecandu narkoba menjalani isolasi. Pendamping akan mengajak mereka agar senantiasa berzikir untuk mengingat Allah hingga jiwanya akan menjadi tenang.

3) Proses Moral-Spiritual

Proses spiritual merupakan hal yang paling terpenting selama mingikuti proses Rehabilitasi di Pusat Rehabilitasi Narkoba ArRahman Palembang. Proses spiritual ini bertujuan untuk membangun benteng pertahanan pecandu narkoba tentang pentingnya pendekatan diri kepada sang pencipta sehingga pecandu narkoba akan senantiasa terjaga dan terkendali dari perbuatan-perbuatan yang dilarang oleh Allah Swt seperti mengkonsumsi narkoba dan melakukan kejahatankejahatan.Adapaun proses spiritual tersebut adalah sebagai berikut: Pertama, mengajarkan pendidikan tentang dasar-dasar keagamaan. Pembekalan dasar-dasar agama di lakukan pada waktu sebelum sholat dzuhur dan setelah sholat magrib. Adapun tata cara dalam memberikan pembekalan dasar-dasar agama yaitu; anak bina dikumpulkan di dalam mushola, kemudian anak bina duduk bersila dan melingkar. Kemudian pembimbing akan mulai memberikan pembekalan tentang dasar-dasar agama seperti tata cara sholat yang baik dan benar, tata cara berzikir dan membaca al-Qur'an.

Kedua, Mewajibkan sholat secara berjamaah. Shalat merupakan ibadah mahdhah yang telah baku dalam Islam. Amalan shalat menjadi metode penyadaran diri yang sangat diutamakan, baik shalat wajib maupun shalat sunnah. Shalat mempunyai dampak yang positif terhadap fisik.Tujuan dari sholat berjamaah adalah untuk 
mengantisipasi bila terjadi kesalahan atau kekurangan dalam rukun sholat agar bisa cepat diluruskan.

Ketiga, berzikir. Zikir dilakukan dengan tujuan untuk meraih ketenangan batin dan untuk mendapatkan ampunan atas dosa-dosa yang telah dilakukan. Dipandang dari sudut kesehatan jiwa, zikir mengandung psikoterapeutik yang mendalam. Kemudian dari segi psikologis, dzikir mengandung kekuatan spiritual yang membangkitkan rasa percaya diri dan rasa optimisme (Hawari, 2009, hal. 17).

Zikir dilakukan dengan tiga tahap, yaitu zikir dengan lisan, zikir dengan hati, dan zikir dengan perbuatan. Zikir dengan lisan dilakukan dengan cara mengucapkan asma Allah, karena mereka sulit untuk menangkap hafalan yang panjang sehingga zikir cukup dengan lafaz "Allah" sebanyak banyaknya. Setelah zikir dengan lisan, mereka dibimbing untuk berzikir dengan hati. Zikir dengan hati dilakukan dengan cara meresapinya di dalam hati hingga terasa pada detak jantung dan denyut nadi, sehingga mereka akan memperoleh ketenangan. Zikir dengan lisan dan hati dilakukan setelah sholat magrib dan sholat subuh. Tingkatan akhir zikir yaitu zikir dengan perbuatan. Zikir dengan perbuatan merupakan zikir yang paling berat dilakukan oleh para pecandu narkoba. Zikir dengan perbuatan dilakukan pada setiap melakukan aktivitas sehari-hari mulai dari bangun tidur hingga menjelang tidur. Rangkaian kegiatan zikir yang dilaksanakan bertujuan untuk mengembalikan kesadaran jiwa pecandu narkoba akan pentingnya agama dalam melandasi semua aktivitas mereka, sehingga diharapkan setelah selesai menjalani proses rehabilitasi, para klien akan mampu menerapkan nilai-nilai spiritual dalam kehidupan sehari-hari.

Keempat, bimbingan membaca al-qurán.Membaca al-Qur'an merupakan salah satu rutinitas yang dilakukan oleh pecandu narkoba setelah sholat magrib. Dalam membaca al-Qur'an, pecandu narkoba diajak untuk duduk melingkar oleh pembimbing. Pembimbing membuka proses pembacaan al-Qur'an dengan pembacaan surah alFatihah, kemudian mulai membaca surah yang lain oleh pecandu narkoba secara bergiliran. Ketika salah satu pecandu narkoba membacakan surah tersebut, maka teman yang lain akan menyimak 
Miswanto dan Tarya

Implementasi Program Rehabilitasi Narkoba Berbasis Masyarakat di Pusat Rehabilitasi Narkoba ar-Rahman Tegal Binangun Palembang

dan mendengarkannya hingga semuanya mendapatkan giliran.Tujuan dari pembacaan al-Qur'an tersebut adalah untuk menenangkan jiwa dan perasaan pecandu narkoba yang sebelumnya jiwa dan perasaan mereka terguncang dan tertekan

2. Faktor Pendukung dan Penghambat

a. Faktor pendukung

Terkait tentang penerapan program rehabilitasi di Pusat Rehabilitasi Narkoba Ar-Rahman ditemukan beberapa faktor yang menjadi pendukung program, diantaranya yaitu:

Pertama, Sarana dan prasarana yang mendukung. Sarana dan prasarana yang ada di Pusat Rehabilitasi Narkoba Ar-rahman sudah cukup baik, karena sudah sesuai dengan kebutuhan pecandu narkoba sehingga dapat menunjang dalam pelaksanaan program rehabilitasi narkoba. Kedua, adanya perhatian dan kasih sayang pembimbing. Konsep perhatian dan kasih sayang di pusat rehabilitasi narkoba Ar-Rahman sangat di utamakan, terutama kepada para pecandu narkoba yang sedang menjalani proses rehabilitasi narkoba. Dengan memberikan perhatian dan kasih sayang, pembimbing akan lebih dekat kepada para pecandu narkoba, sehingga akan sangat mendukung dalam merealisasikan program.

Ketiga, adanya niat dan kemauan kuat dari pecandu narkoba. Niat merupakan modal terpenting dalam proses pemulihan bagi pecandu narkoba. Niat yang kuat akan mempengaruhi tingkah laku pecandu narkoba selama mengikuti proses rehabilitasi.

Keempat, adanya dukungan dari pemerintah. Dukungan pemerintah sangatlah membantu dalam mendukung terealisasinya program rehabilitasi di Pusat Rehabilitasi Narkoba Ar-Rahman Palembang. Dukungan yang diberikan tidak hanya pada bentuk fisik bangunan saja, tetapi juga berbentuk pelatihan-pelatihan yang diberikan kepada pengurus Pusat Rehabilitasi Narkoba Ar-Rahman Dengan adanya bantuan sarana dan prasarana, maupun pelatihan-pelatihan di daerah maupun pusat, pihak pengelola akan lebih optimal dalam merealisasikan program rehabilitasi narkoba.

b. Faktor Penghambat

Ada beberapa faktor penghambat yang ditemukan selama proses rehabilitasi narkoba di Pusat Rehabilitasi Narkoba Ar-rahman Palembang. Adapun faktor-faktor tersebut antara lain; 
Pertama, keadaan pecandu yang parah.Pelaksanaan program rehabilitasi akan terhambat apabila pecandu narkoba memiliki penyakit yang parah, baik penyakit yang disebabkan karena mengkonsumsi narkoba maupun penyakit lain seperti penyakit jantung, diabetes dan lain-lain.Keadaan jasmani dan rohani pecandu narkoba sangat mempengaruhi proses aktivitas sehari-hari dalam mengikuti program rehabilitasi.

Kedua, tidak adanya dukungan dari keluarga.Pada masa proses rehabilitasi, perhatian dan kasih sayang orang tua sangat di butuhkan agar anak merasa termotivasi untuk lekas sadar atas apa yang telah di perbuatnya selama ini.Kurang adanya perhatian keluarga ataupun orang tua merupakan salah satu hambatan pengasuh dalam upaya penyadaran. Kurangnya dukungan tersebut dapat dilihat dari sedikitnya orang tua atau keluarga yang mengunjungi anaknya di rehabilitasi Narkoba Ar-Rahman Palembang.Orang tua pecandu narkoba terkadang merasa minder dan malu karena anaknya telah melakukan perbuatan-perbuatan yang tidak sesuai dengan harapan kedua orang tua dan masyarakat, sehingga orang tua akan menunjukkan perhatian yang kurang kepada anak bahkan terkesan membiarkan saja.

\section{Output Program Rehabilitasi}

a. Adanya perubahan perilaku dan mental

Sebelum masuk di Pusat Rehabilitasi Narkoba Ar-Rahman Palembang, anak bina menunjukkan sikap perlawanan kepada orang tua dan suka berbohong, hingga akhirnya setelah masuk dan mengikuti program pembinaan di Pusat Rehabilitasi Narkoba Ar-Rahman anak terlihat patuh, rajin peduli lingkungan dan suka berbaur kepada orang lain. Bentuk perilaku peduli lingkungan dari pantauan peneliti adalah anak bina melakukan pembersihan sampah-sampah hingga mencabuti rumputrumput yang ada di lingkungan rehabilitasi. Bahkan mereka terkesan tidak ingin istirahat dan ingin melakukan aktivitas secara terus menerus hingga mereka benar-benar berkeringat. Di sela-sela melakukan pembersihan mereka terdengar melafazkan zikir. Adapun zikir yang terdengar oleh peneliti adalah lafaz Allah dan istighfat dengan nada yang pelan.

b. Munculnya kesadaran untuk berhenti mengkonsumsi narkoba

Output dari proses rehabilitasi narkoba di Pusat Rehabilitasi Narkoba ArRahman yang selanjutnya adalah munculnya kesadaran untuk berhenti mengkonsumsi narkoba. Hal tersebut dapat dilihat dari pernyataan klien 
Miswanto dan Tarya

Implementasi Program Rehabilitasi Narkoba Berbasis Masyarakat di Pusat Rehabilitasi Narkoba ar-Rahman Tegal Binangun Palembang

yang sedang menjalani proses rehabilitasi narkoba maupun klien yang sudah keluar dari Pusat Rehabilitasi Narkoba Ar-Rahman Palembang. Yang menyatakan bahwa tingkah laku, kebiasaan dan rasa ketergantungan terhadap narkoba bisa di rubah. Walaupun dalam merubahannya membutuhkan proses yang tidaklah mudah. Dengan munculnya perubahan-perubahan tersebut, akan memunculkan semangat-semangat baru.

c. Munculnya ketaatan dalam beribadah

Berkaitan dengan ketaatan ibadah yang ada di Pusat Rehabilitasi Narkoba Ar-Rahman Palembang adalah ketaatan ibadah sholat, zikir dan membaca al-Quran. Ketaatan dalam menjalankan ibadah pada diri pecandu narkoba tentunya tidak serta muncul dengan sendirinya. Ada beberapa faktor yang mempengaruhi pecandu narkoba untuk taat dalam menjalankan ibadah, salah satunya adalah adanya pemaksaan dari pembimbing/pengurus, dan adanya niat yang kuat.proses spiritual yang diterapkan di Pusat Rehabilitasi Narkoba Ar-Rahman mulai dari sholat, berzikir dan membaca al-Qur'an adalah untuk membiasakan diri agar senentiasa dekat kepada Allah Swt.

d. Persentase kesadaran pecandu narkoba meningkat

e. Keberhasilan program rehabilitasi narkoba dapat dilihat dari jumlah klien yang berhasil sadar selama mengikuti progam rehabilitasi. Adapun persentase kesadaran klien pusat rehabilitasi narkoba Ar-rahman dapat dilihat pada gambar berikut:

\section{Tabel 5}

Grafik Kesadaran Klien Pusat Rehabilitasi Narkoba Tahun 2012-2016

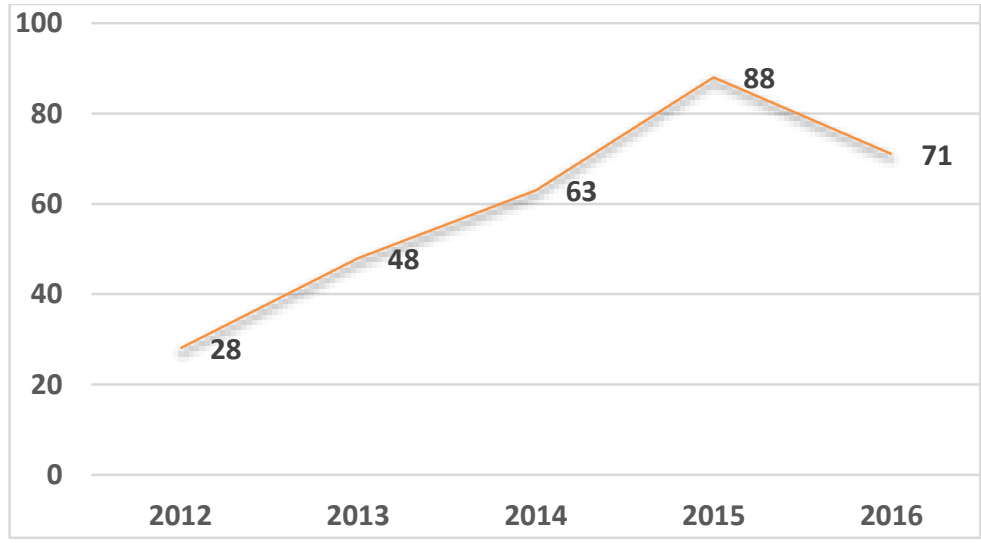


Dari data jumlah klien dari tahun 2012-2016 yang berjumlah 340, tentu keberhasilan tidak mencapai $100 \%$. Hal ini dikarenakan beberapa faktor. Diantaranya yaitu: split dan pulang kerumah tanpa kembali lagi ke rehabilitasi. Split adalah melarikan diri yang dipicu (triger factor) emosional psikologis yang mengakibatkan klien mencoba untuk melarikan diri dari pusat rehabilitasi.

Adapun data selama 5 tahun terakhir tersebut adalah yang melarikan diri dari tempat rehabilitasi hanya 10 orang, tetapi kalau yang sedang pulang ke rumah dan tidak kembali lagi itu ada 32 klien. Dengan rincian tahun $2012=2$ kabur 4 pulang, $2013=3$ kabur 3 pulang, $2014=2$ kabur 7 pulang, $2015=2$ kabur, 10 pulang, 2016 = 1 kabur 8 pulang. Karena pada dasarnya pecandu tidak senang terhadap peraturan yang menurutnya terlalu mengekang (Novizar, 2016).

Apabila jumlah diatas dipersentase keberhasilan kesembuhan dalam proses rehabilitasi yang dilakukan di pusat rehabilitasi narkoba ArRahman Palembang selama lima tahun terakhir adalah 87,5\% pecandu narkoba bisa sadar kembali dan bisa sehat kembali jasmani dan rohaninya setelah mengikuti proses rehabilitasi dan 12,5\% tidak berhasil dibina karena melarikan diri dan pulang kerumah akan tetapi tidak kembali lagi ke pusat rehabilitasi Narkoba Ar-Rahman.

\section{Kesimpulan}

Dari uraian di atas tentang implementasi program rehabilitasi narkoba berbasis masyarakat di Pusat Rehabilitasi Narkoba Ar-Rahman Palembang dapat disimpulkan berdasarkan pokok permasalahan, sebagai berikut:

1. Implementasi program rehabilitasi narkoba melalui tiga tahap yaitu, tahap biologis-medis, psikoterapi-psikologi, dan tahap moral-spiritual. Pada tahap biologis-medis meliputi; detoksifikasi, mandi, dan memotong rambut serta kuku. Tahap psikoterapi-psikologi meliputi; isolasi dan motivasi, tahap terakhir adalah tahap moral-spiritual meliputi; pendidikan dasar-dasar agama, sholat berjama'ah, zikir dan membaca al-Qur'an.

2. Dalam mengimplementasi program rehabilitasi narkoba, terdapat faktor pendukung dan penghambat, faktor pendukung yaitu; sarana prasarana yang mendukung, adanya perhatian dan kasih sayang pembimbing, dan adanya dukungan dari pemerintah. Faktor penghambat yaitu; keadaan pecandu yang parah dan tidak adanya dukungan dari orang tua. 
Miswanto dan Tarya

Implementasi Program Rehabilitasi Narkoba Berbasis Masyarakat di Pusat Rehabilitasi Narkoba ar-Rahman Tegal Binangun Palembang

3. Dari pengimplementasian program rehabilitasi narkoba yang berujung pada proses spiritual di Pusat Rehabilitasi Narkoba Ar-Rahman secara garis besar telah berhasil menumbuhkan kesadaran pada pecandu narkoba untuk berhenti mengkonsumsi narkoba. hal tersebut dapat dilihat dari output program rehabiilitasi narkoba antara lain; adanya perubahan perilaku dan mental, munculnya kesadaran untuk berhenti mengkonsumsi narkoba, munculnya ketaatan dalam beribadah, dan meningkatnya persentase kesadaran pecandu narkoba 


\section{Daftar Pustaka}

Charisa, A. (2016). Psikologi Motivasi. Retrieved from Psikologi Motivasi: www.academia.edu/9760314/psikologi_motivasi

Hawari, D. (1996). Al-Qur'an Ilmu Kedokteran Jiwa dan Kesehatan Jiwa. Jakarta: Dana Bakti Prima Yasa.

Hawari, D. (2009). Integrasi Agama dalam Pelayanan Medik. Jakarta: FKUI.

Indonesia, B. N. (2008). Pencegahan Penyalahgunaan Narkoba Sejak Usia Dini. Jakarta: BNN.

News, D. (2016, Maret 22 ). Detik News. Retrieved from Jokowi: Tutup Pintu Masuk Narkoba dan Sidak Lapas Sebulan Sekali: https://news.detik.com/

Novizar. (2016). Program Rehabilitasi Narkoba. (Miswanto, Interviewer)

Nuraini, D. N. (2014). Kedahsyatan Terapi Detoks. Jakarta: Padi.

Sahrizal. (2016). Program Rehabilitasi Narkoba. (Miswanto, Interviewer)

Sumsel, K. B. (2016, September 7). Anti Narkoba. (D. News, Interviewer) 
Miswanto dan Tarya

Implementasi Program Rehabilitasi Narkoba Berbasis Masyarakat di Pusat Rehabilitasi Narkoba ar-Rahman Tegal Binangun Palembang

Intizar, Volume 23, Nomor 1, 2017 